\title{
こんなところに複合材料
}

\section{一エネルギー関連用途と CFRP}

\author{
桶 口 徹 憲
}

\section{1. は じめに}

炭素繊維強化プラスチック (CFRP) は比強度・比弾 性率が高く, 化学的に安定で, 熱的・電気的特性に優れ るという特長を活かし, 航空・宇宙, スポーツ, 産業用 途等で幅広く使用されている.

CFRP が使用される用途をさらに分類し, 成長率を まとめたのが表 1 であるが, 特に産業用途アイテムの伸 びが著しいことがわかる，また，航空・宇宙やスポーツ (ゴルフ, ラケット, 釣り) はこれまでCFRP の拡大に 寄与してきた分野であり, 将来的にも安定した成長が見 込まれている。

本シリーズ「こんなところに複合材料」の中では既に 「土木・建築分野でのピッチ系高弾性炭素瀻維の利 用1)」,「自動車用途での CFRP ${ }^{2)}$ ，「釣竿における複合 材料 $\left.{ }^{3}\right\rfloor$ 等でCFRP が取り上げられている.

今回はさらなる高成長が期待される産業用途から, 「クリーン」と「効率化」をキーワードにエネルギー用 途に関連する CFRP を取り上げることにする.

以下，用途展開について詳細を記す。

\section{2.エネルギー関連の用途展開}

\subsection{CNG (Compressed natural gas) タンク}

CNGタンクについては既に「自動車用途での CFRP」にも取り上げられているが，ここでは少し詳細 に説明を加える。

$\mathrm{CNG}$ とは圧縮天然ガスのことであり，図 1 に CNG 自動車の構造を示したが, 自動車用燃料を従来のガソリ ンから CNGに代える場合, 自動車後部にガソリンタン クに代わる高圧容器, すなわち CNG タンクを設置する 必要がある。

現在, 無公害車のエネルギー源として電気も有力であ

Tetsunori HIGUCHI：東レ(侏複合材料研究所 (7913120 愛媛県伊予郡松前町大字筒井 1515）
るが，ガソリンを CNG に代替することにより，CO や $\mathrm{SO}_{\mathrm{x}}, \mathrm{NO}_{\mathrm{x}}$ が大幅減少するため, $\mathrm{CNG}$ はクリーンな低 公害燃料として位置付けられる (図 2).

CNG 自動車に関する米国ビックスリーの動向は表 2 のとおりである. また，昨年ホンダ車でCFRPを用い たプラスチック製 CNG タンクが実用化された4).

この CNG タンクを材料別に重量を比較すると表 3 の ように鋼製タンクに対して，アルミニウム製ライナーを GFRP で補強したタンクで重量が削減できるが,さら にプラスチック製ライナーをCFRP で補強したタンク はさらに重量を大幅に削減できる．価格はGFRP（ガ ラス繊維強化プラスチック）を補強したタンクょりやや 高くなるものの, 重量減による燃費向上を含めたトータ ルコストダウンという意味で有利である.

なお，CFRPの補強としては図 3 に示したようにへ リカル巻きとフープ巻きという方式がある.

\section{2 フライホイール (Fly wheel)}

フライホイールとは円盤形状のエネルギー蓄積体で, エネルギーを回転体の運動エネルギーとして蓄積する. 主として電気エネルギーを蓄える目的で使用され, 最近 注目されている.

フライホイールバッテリーとは図 4 のような構造であ り,ロータ部のみを取り出した写真も併せて示した。工 ネルギー密度の式(図 4 中)から理解できるように, エネ ルギー密度を大きくするのは高強度かつ低密度材料であ る. CFRPは格好といえる。

ロータ部をCFRP 化することによってスチール製の 実に約 3.8 倍のエネルギー貯蔵ができる.

フライホイールが実際使用される具体例として, バッ クアップ電源用バッテリー, 夜間電力貯蔵・電力平準化 用の発電所用途, 自動車用途などを想定している.

\section{3 風車ブレード (Wind blade)}

最近, 原子力エネルギーについて議論されることが多 いが, 将来のクリーンなエネルギー源の一つとして有望 なのが風力発電である. 立地条件が限定される問題があ 
表 1 用途別の成長率

\begin{tabular}{|c|c|c|c|}
\hline 用 途 & アイテム & 使 用 例 & 成長率（\%/年） \\
\hline 産 & $\begin{array}{l}\text { 高圧容器 } \\
\text { 土建築 } \\
\text { 輸送機 器 } \\
\text { エネルギー } \\
\text { 機械部品等 } \\
\text { その 他 }\end{array}$ & $\begin{array}{l}\text { CNG タンク, 空気呼吸器 } \\
\text { 橋脚補強, 建築材料 } \\
\text { ボート, } \\
\text { フライホック, 自動車, 列車 } \\
\text { ロール, パイブ, コンテナー 風 } \\
\text { コンパウンド, 医療機器等 }\end{array}$ & 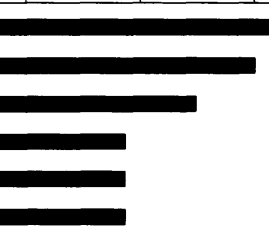 \\
\hline スポーツ & $\begin{array}{lll}\text { ゴ } & \text { フ } \\
\text { ラケッ } & \text { ケ } \\
\text { 釣 } & & \text { ク }\end{array}$ & $\begin{array}{l}\text { カーボンシャフト比率 } 60 \% \rightarrow 90 \% \\
\text { 日・米市場は成熟 } \\
\text { アジア諸国では拡大 }\end{array}$ & \\
\hline 航空・宇宙 & 航 空 機 & $\begin{array}{l}\text { ボーイング } 777 \\
\text { 通信衛星 }\end{array}$ & \\
\hline
\end{tabular}

表 2 米国ビッグスリーの動向

\begin{tabular}{lllll}
\hline \hline & \multicolumn{1}{c}{ 車 種 } & \multicolumn{2}{c}{ モデル (年) } & \multicolumn{1}{c}{ 備 考 } \\
\hline フォード & 乗用車 & Crown Victoria & ('96) & 警察, タクシー \\
クライスラー & バン & - & (現行車) & 実験車 \\
& 小型バン & - & (現行車) & 実験車 \\
& 乗用車 & Intrepid & (現行車) & ハイブリッド燃料車 \\
& 小型トラック & T300/Dakota & ('95) & \\
GM & ホ型トラック & - & (現行車) & 実験車 \\
& バン & - & (現行車) & 実験車 \\
\hline
\end{tabular}

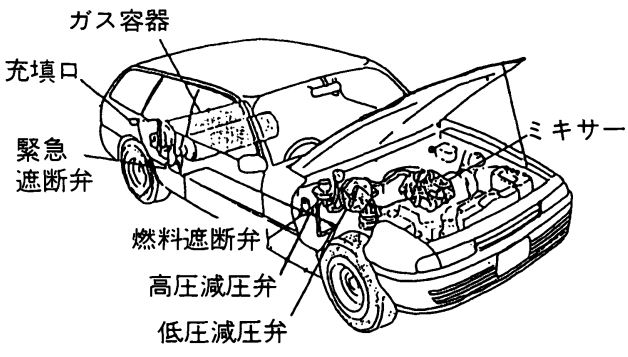

図 1 CNG 自動車の構造

るが，無尽蔵とも言える風力を利用した発電システムは 魅力的である.

図 5 はプロペラ型風車による発電システムをモデル化 して示したものであり, 現在, 風車ブレードは 3 枚ブレ 一ドが振動も少なく, 安定性が良好なため主流となって いる.

このブレード材は軽量で耐久性のあることが要求さ れ, 現在 GFRP が主でCFRPが一部使用されている が, 将来さらに効率的にエネルギーを発生させるにはブ

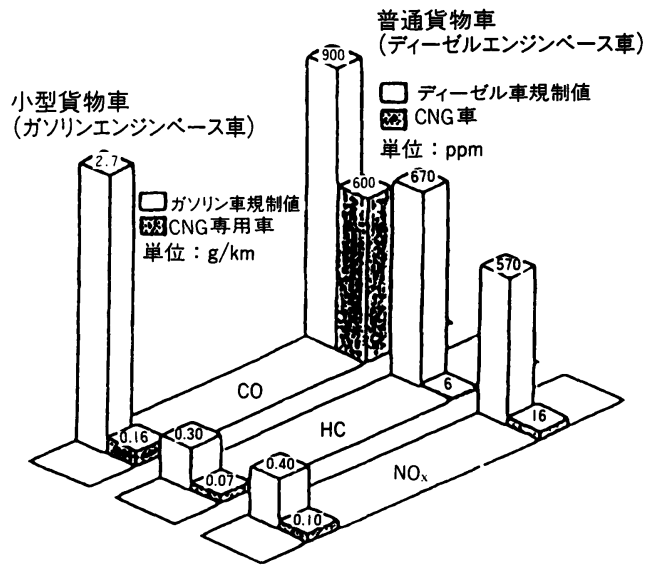

図 2 排ガス比較

レードを大型化していく必要があり，比剛性と比強度に 優れた CFRP が主流となると予想されている.

\section{3. 今後の展望}

CFRP はその優れた特性によって，今回取り上げた 
表 3 CNG タンク : 容器材料比較

\begin{tabular}{cccrc}
\hline \hline \multicolumn{1}{c}{ 材 料 } & $\begin{array}{c}\text { 容器 } \\
(l)\end{array}$ & $\begin{array}{r}\text { 重量 } \\
(\mathrm{kg})\end{array}$ & $\begin{array}{c}\text { 価格 } \\
(\$)\end{array}$ \\
\hline 鋼 & & 76 & 110 & 400 \\
$\mathrm{Al}$ ライナー & GFRP & 74 & 70 & 800 \\
プラスチック & GFRP & 70 & 50 & 400 \\
ライナー & CFRP & 70 & 20 & 600 \\
\hline
\end{tabular}

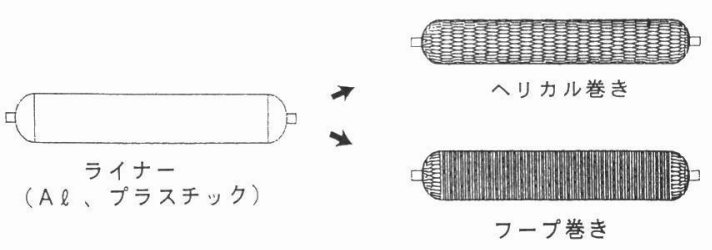

図 3 FRP 容器の補強方式
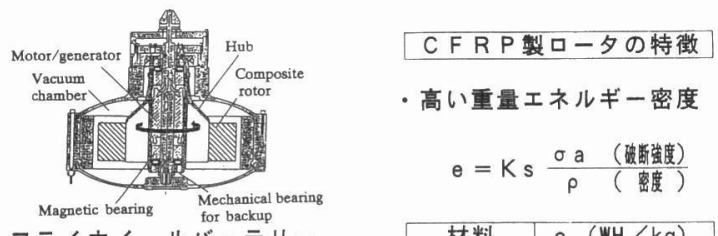

・高い重量エネルギー密度

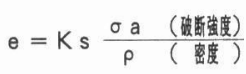

フライホイールバッテリー

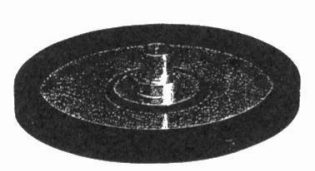

C F R P 製ロータ

図 4 フライホイール

エネルギー関連を支える用途を含め，今後ますます重要 な材料として位置付けられると予想している.

産業用途では, 特にCFRP で従来材料に置き換える

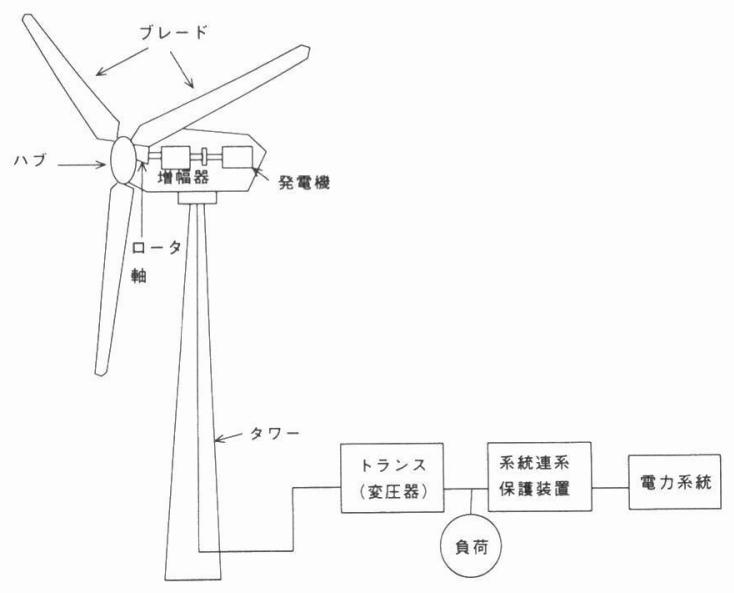

図 5 風車発電システム

ことがコスト的に難しいというイメージをなかなか払拭 しきれなかった。しかし阪神・淡路大震災以降の CF の 耐震補強工法の躍進以降はイメージが大きく変わった。

今後, 炭素繊維扔よびその加工プロセスの低コスト化 を進めることはもちろんであるが，設計の標準化，ユー ザーの認知・協力, 周辺技術のレベルアップ, 環境問題 の実証等の課題を解決し，さらなる用途展開を行ってい く必要がある.

\section{参 考 文 献}

1）林田道弥：日本複合材料学会誌，25，1 (1999), 30-37.

2）魚谷真一郎，柳澤正良，伊藤京一：日本複合材料学 会誌, 25, 6 (1999), 236-239.

3）黑川智弘：日本複合材料学会誌，25，3 (1999), 122-126.

4）ホンダ技研工業，“シビック GV”資料（1998）. 